Portland State University

PDXScholar

$1-1-1998$

\title{
Intrapopulation Sex Ratio Variation in the Salt Grass Distichlis spicata
}

\author{
Sarah M. Eppley \\ Portland State University, eppley@pdx.edu \\ Maureen L. Stanton \\ University of California - Davis \\ Richard K. Grosberg \\ University of California - Davis
}

Follow this and additional works at: https://pdxscholar.library.pdx.edu/bio_fac

Part of the Plant Biology Commons, and the Plant Breeding and Genetics Commons

Let us know how access to this document benefits you.

\section{Citation Details}

Sarah M. Eppley, Maureen L. Stanton, and Richard K. Grosberg, "Intrapopulation Sex Ratio Variation in the Salt Grass Distichlis spicata,' The American Naturalist, Vol. 152, No. 5 (November 1998), pp. 659-670

This Article is brought to you for free and open access. It has been accepted for inclusion in Biology Faculty Publications and Presentations by an authorized administrator of PDXScholar. Please contact us if we can make this document more accessible: pdxscholar@pdx.edu. 


\section{Intrapopulation Sex Ratio Variation in the Salt Grass Distichlis spicata}

Sarah M. Eppley, ${ }^{\star}$ Maureen L. Stanton, $\dagger$ and Richard K. Grosberg $\ddagger$

Center for Population Biology, University of California, Davis, California 95616

Submitted September 19, 1997; Accepted May 11, 1998

ABSTRACT: In many dioecious plant populations, males and females appear to be spatially segregated, a pattern that is difficult to explain given its potentially high costs. However, in asexually propagating species, spatial segregation of the sexes may be indistinguishable from superficially similar patterns generated by random establishment of a few genets followed by extensive clonal spread and by gender-specific differences in rates of clonal spread. In populations where a significant fraction of individuals are not flowering and gender cannot be assigned to this fraction, apparent spatial segregation of the sexes may be due to differential flowering between the sexes. We confirm reports that flowering ramets of the clonal, perennial grass Distichlis spicata are spatially segregated by sex. We extend these studies in two fundamental ways and demonstrate that this species exhibits true spatial segregation of the sexes. First, using RAPD markers, we estimated that at least $50 \%$ of ramets in patches with biased sex ratios represent distinct genotypes. Second, we identified a RAPD marker linked to female phenotype (eliminating the possibility that gender is environmentally determined) and used it to show that the majority of patches exhibit significantly biased sex ratios for both ramets and genets, regardless of flowering status.

Keywords: sex ratio, spatial segregation, bulked segregant analysis, RAPD.

Sexual reproduction in eukaryotes requires that male and female gametes encounter one another. In most sessile dioecious organisms, wind, water, or animals transport gametes from one individual to another. All else being equal, as the average distance between males and females increases in a population, the likelihood that male and female gametes will come into contact with one another

\footnotetext{
*E-mail: smeppley@ucdavis.edu.

$\dagger$ E-mail: mlstanton@ucdavis.edu.

‡ E-mail: rkgrosberg@ucdavis.edu.

Am. Nat. 1998. Vol. 152, pp. 659-670. (๑ 1998 by The University of Chicago. 0003-0147/98/5205-0001\$03.00. All rights reserved.
}

should decline, potentially limiting both male and female reproductive success (Bawa and Opler 1977; Pennington 1985; Yund 1990; Levitan 1991; Babcock and Mundy 1992; Brazeau and Lasker 1992; Levitan et al. 1992; Cresswell et al. 1995; Burczyk et al. 1996). Thus, to the extent that opportunities for fertilization restrict the reproductive success of sessile, dioecious organisms, it would be surprising to find that males and females are spatially segregated by sex. Indeed, in the vast majority of cases, males and females are well mixed (Bawa and Opler 1977; Melampy and Howe 1977; Hancock and Bringhurst 1980; Bullock 1982; Lovett Doust et al. 1987; Armstrong and Irvine 1989; Yund and Parker 1989; Guitian 1995).

Nevertheless, in many dioecious plant species, males and females are spatially segregated, suggesting either that fertilization does not limit reproductive success or that the benefits of such segregation outweigh the costs. Freeman et al. (1976) first described this phenomenon in three species: salt grass (Distichlis spicata), meadow rue (Thalictrum fendleri), and box elder (Acer negundo). Since that time, spatial segregation of males and females has been documented in over 25 plant species from 18 families (see Bierzychudek and Eckhart 1988 for a review; see Korpelainen 1991 and Shea et al. 1993 for more recent examples), and Bierzychudek and Eckhart (1988) named the pattern "spatial segregation of the sexes" (SSS). Spatial segregation of the sexes may arise from several proximate mechanisms including environmental sex determination; gender-specific differences in germination requirements, seedling mortality, and adult mortality; heritable variation for offspring sex ratio in concert with limited dispersal of seeds; and active habitat selection (Bierzychudek and Eckhart 1988; Houssard et al. 1994; Taylor 1996).

For two reasons, most previous studies have failed to identify the mechanisms underlying spatial segregation of the sexes. The first problem arises because most plants for which segregation of the sexes has been documented can propagate asexually. Almost exclusively, previous studies have measured spatial segregation of ramets (morphologically distinct modules) without regard to whether each ramet represents a unique genotype (i.e., 


\section{The American Naturalist}

genet). If ramets, not genets, are surveyed, true spatial segregation of the sexes may be indistinguishable from superficially comparable patterns generated by the random establishment of a few genets followed by extensive periods of clonal spread (Hoffmann 1986; Iglesias and Bell 1989) and by differential clonal growth rates between male and female genets in different microhabitats. The random establishment of a few genets followed by clonal spread would result in patches with biased sex ratios, but each patch would consist of only one or a very few genets. Gender-specific differences in clonal growth rates would also result in patches with biased sex ratios of ramets, but the genet sex ratio of each patch would be $1: 1$, with larger genets of one sex than the other.

The second problem concerns determining the gender of nonflowering plants. For example, Lloyd (1973), Freeman et al. (1976), Cox (1981), Wade et al. (1981), and Shea et al. (1993) assessed gender only for flowering individuals and were unable to sex a portion of the population. Failure to reckon gender of both flowering and nonflowering individuals can bias estimates of sex ratios (Meagher 1984; Cipollini and Stiles 1991). Accordingly, if a large portion of a population is not flowering and individuals can only be sexed if they are in flower, then the documented spatial pattern may reflect spatial segregation among sexually reproductive plants only rather than true spatial segregation of male and female genotypes.

Freeman et al. (1976) showed that salt grass (D. spicata) exhibits spatial segregation of flowering ramets along transects at a single site in California. Bertness et al. (1987) recorded a similar pattern in an East Coast population. However, neither study documented spatial distributions for nonflowering ramets nor distinguished ramets from genets. In this study, we reexamine this pattern in D. spicata with a more intensive survey in three sites and confirm that these D. spicata populations also show spatial segregation of flowering ramets. We use RAPD-PCR markers to address the following four questions aimed at clarifying the processes underlying this pattern. Do patches with biased sex ratios of flowering ramets consist of many genets or just a few? Is there evidence of gender-specific differences in clonal growth rates in different microhabitats? Are both flowering and nonflowering individuals spatially segregated by gender? Is sex determined environmentally or genetically?

\section{Material and Methods}

\section{The Study System}

Distichlis spicata is a clonal, salt-tolerant, dioecious perennial grass that is common in both west and east coast salt marshes of the United States (Hitchcock 1971, pp. 175-177). In addition, an inland variety lives in salty and alkaline soils throughout the central United States (Beetle 1943). Pollen is wind dispersed. Ramet densities in salt marsh populations are typically very high, and individual plants propagate asexually by rhizomes (Beetle 1943; Hitchcock 1971, pp. 175-177), forming long, linear runners. We studied three discrete D. spicata populations that lie along a $35-\mathrm{km}$ stretch of the coast in north central California: the Limantour estuary (approximately 35,000 $\mathrm{m}^{2}$ ) in the Point Reyes National Seashore, Audobon Canyon Ranch's Walker Creek estuary (approximately $150,000 \mathrm{~m}^{2}$ ) at Tomales Bay, and an estuary (approximately $10,000 \mathrm{~m}^{2}$ ) at the Bodega Bay Marine Laboratory.

\section{Documentation of Spatial Distribution of Flowering Ramet}

In 1995, we conducted a survey of spatial segregation of sexually reproductive ramets at Point Reyes, Tomales Bay, and Bodega Bay. A preliminary survey of flowering ramets suggested that interspersed within a single population of D. spicata are many areas with female majorities and many areas with male majorities. We used focal plant surveys to quantify this pattern. Using a map of each site, we divided the D. spicata habitat into quadrats of $10 \mathrm{~m} \times 10 \mathrm{~m}$ and randomly chose a flowering focal ramet within each quadrat. At Point Reyes, from a total of 96 quadrats, we randomly chose $30-21$ of these had male focal plants and nine had female focal plants. At Tomales Bay, from 223 total quadrats, we randomly selected quadrats until we had 30 with male focal plants and 30 with female focal plants. At Bodega Bay, from 85 total quadrats, we randomly chose until we had 33 quadrats with male focal plants and 33 with female focal plants. For each focal plant in these quadrats, we recorded the sex of the nearest flowering ramet at $1-\mathrm{m}$, 2-m, 3-m, 4-m, and 5-m intervals along each of the cardinal directions, thus, systematically surveying four radii of a $78-\mathrm{m}^{2}$ circle around each focal plant.

\section{Plant Tissue Collection}

To minimize costs, we collected tissue samples for RAPD-PCR analysis at only two study sites, Point Reyes and Tomales Bay. Within the Point Reyes site, from 96 total $10 \times 10-\mathrm{m}$ quadrats, we randomly chose two with focal male plants and two with focal female plants. These focal male and focal female plants were separated by at least $25 \mathrm{~m}$. At Tomales Bay, from 223 total quadrats, we chose three with male focal plants and three with female focal plants. At this site, the distance between focal male and focal female plants ranged from $65 \mathrm{~m}$ to $300 \mathrm{~m}$.

We determined the sex of the nearest flowering ramet 

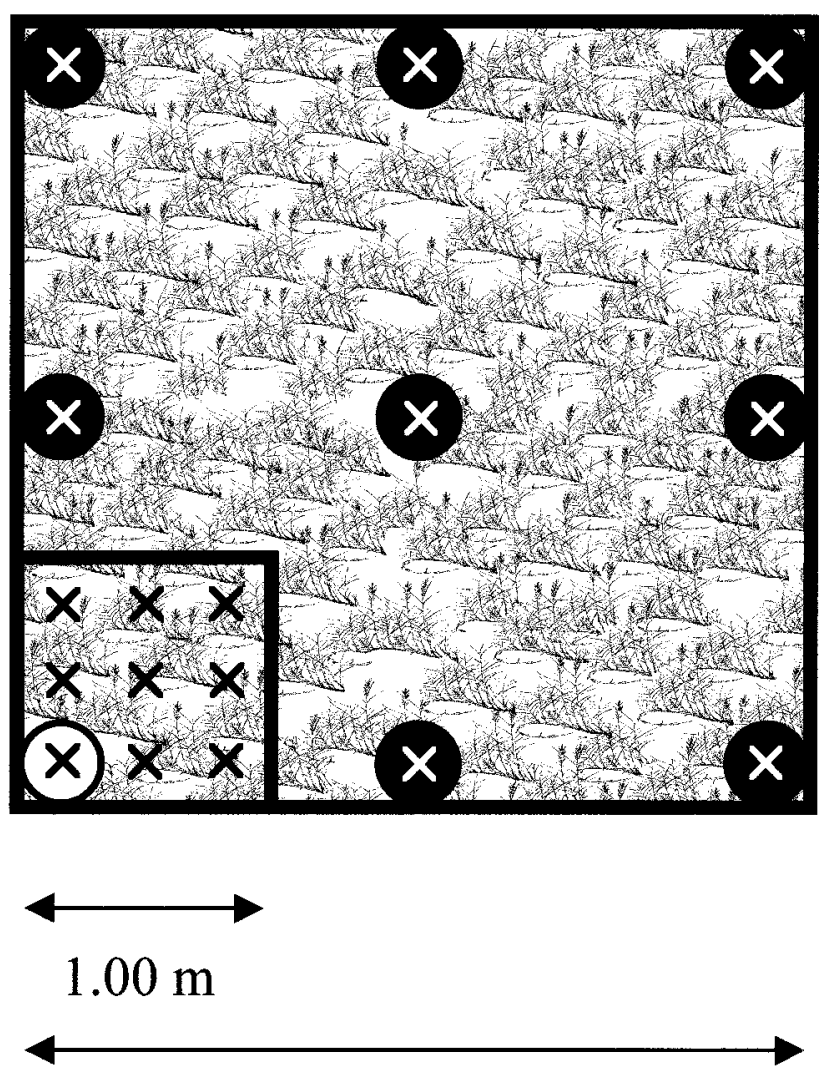

\section{$3.16 \mathrm{~m}$}

Figure 1: A diagram showing the quadrat sets used for collecting plant tissue. Each quadrat set is composed of a pair of $1-\mathrm{m}^{2}$ $(1.00 \times 1.00 \mathrm{~m})$ and $10-\mathrm{m}^{2}(3.16 \times 3.16 \mathrm{~m})$ nested quadrats, with a total of 17 samples per quadrat set. An $X$ indicates each sample from the $1-\mathrm{m}^{2}$ quadrat. An $X$ in a closed circle indicates each sample from the $10-\mathrm{m}^{2}$ quadrat. The $X$ in the open circle indicates the one sample included in both quadrats.

to each of 100 random points within a 10 -m radius of each of the 10 focal plants. We then used the ratio of male to female flowering ramets to classify each circular area as either male or female majority sex. Next, on each of the focal plants, we centered a $10-\mathrm{m}^{2}$ quadrat $(3.16 \times$ $3.16 \mathrm{~m}$ ) with nine sampling points (fig. 1). In one corner of each $10-\mathrm{m}^{2}$ quadrat, we positioned a $1-\mathrm{m}^{2}$ quadrat with an additional eight sampling points (fig. 1). We attempted to sample a leaf from one ramet at each of the 17 points, but in four of the 10 quadrats, no D. spicata plant occurred within a $0.25-\mathrm{m}$ radius of at least one designated sampling point. The number of samples per quadrat therefore ranged from 13 to 17 ramets. We transported the collected leaves on ice to the University of California, Davis, and stored them at $-80^{\circ} \mathrm{C}$. To estimate the fraction of the total population of ramets that the samples represented in a given area, we counted the number of D. spicata ramets in $0.005-\mathrm{m}^{2}$ quadrats at Tomales Bay (33 quadrats) and determined average ramet densities.

\section{RAPD Analysis}

We extracted DNA using a modification (F. Ryan, personal communication) of the procedure developed by Saghai-Maroof et al. (1984). We ground $100 \mathrm{mg}$ of frozen tissue in liquid nitrogen, added $100 \mathrm{~mL}$ CTAB extraction buffer (2 g CTAB, $35 \mathrm{~mL} 4-\mathrm{M} \mathrm{NaCl}, 4 \mathrm{~mL}$ 0.5-M EDTA, water to $100 \mathrm{~mL}$ ), and incubated the tissue and buffer for $1 \mathrm{~h}$ at $65^{\circ} \mathrm{C}$. We centrifuged each sample for $10 \mathrm{~min}$ at 10,000 rpm and extracted it in a 24:1 mixture of chloroform: isoamyl alcohol $(700 \mu \mathrm{L})$. We precipitated the DNA with $2-\mathrm{M}$ sodium acetate $(70 \mu \mathrm{L})$ and $100 \%$ isopropanol $(700 \mu \mathrm{L})$ and stored samples overnight at $-20^{\circ} \mathrm{C}$. After centrifuging the samples for $10 \mathrm{~min}$ at $10,000 \mathrm{rpm}$, we poured off the supernatant, washed the DNA twice with $70 \%$ ethanol, centrifuged the samples again for $5 \mathrm{~min}$ at $5,000 \mathrm{rpm}$, and left them to dry for 2$3 \mathrm{~h}$. Finally we resuspended the DNA in $100 \mu \mathrm{L}$ glassdistilled water.

We screened decamer primers (Operon Technology, Alameda, Calif.) using a $25-\mu \mathrm{L}$ PCR amplification reaction, cycling profiles, and electrophoretic analysis following procedures established earlier (Levitan and Grosberg 1993). We stopped screening primers for detectable polymorphisms when we determined that additional polymorphic markers failed to distinguish additional genotypes (Hunter 1993).

Three individual samples were haphazardly chosen for preliminary analysis. From the 89 primers we screened with these three samples, we chose 11 (OPF-07, OPF-16, OPF-19, OPR-16, OPU-09, OPZ-17, OPAD-13, OPAJ-3, OPAJ-12, OPAJ-13, OPAJ-20). We selected these primers because they consistently yielded a total of 108 easily detectable polymorphic bands. To be as conservative as possible in our estimates of the number of separate genets determined within a given area using these primers, we identified the 29 bands between the narrow range of 250-1,500 base pair (bp) for which amplification was not affected by a threefold variation in DNA concentration and for which identification was not confounded by the presence of other bands of a similar size. Furthermore, to ensure the consistency of the banding patterns, we repeated 12 DNA isolations and 189 RAPD amplifications on different days and with different stock solutions. RAPD primers always amplified the same bands from DNA from the same individual.

We used the 11 primers to amplify DNA from samples at six locations at Tomales Bay. To minimize the effects of variation in sampling, extraction, and PCR amplifica- 


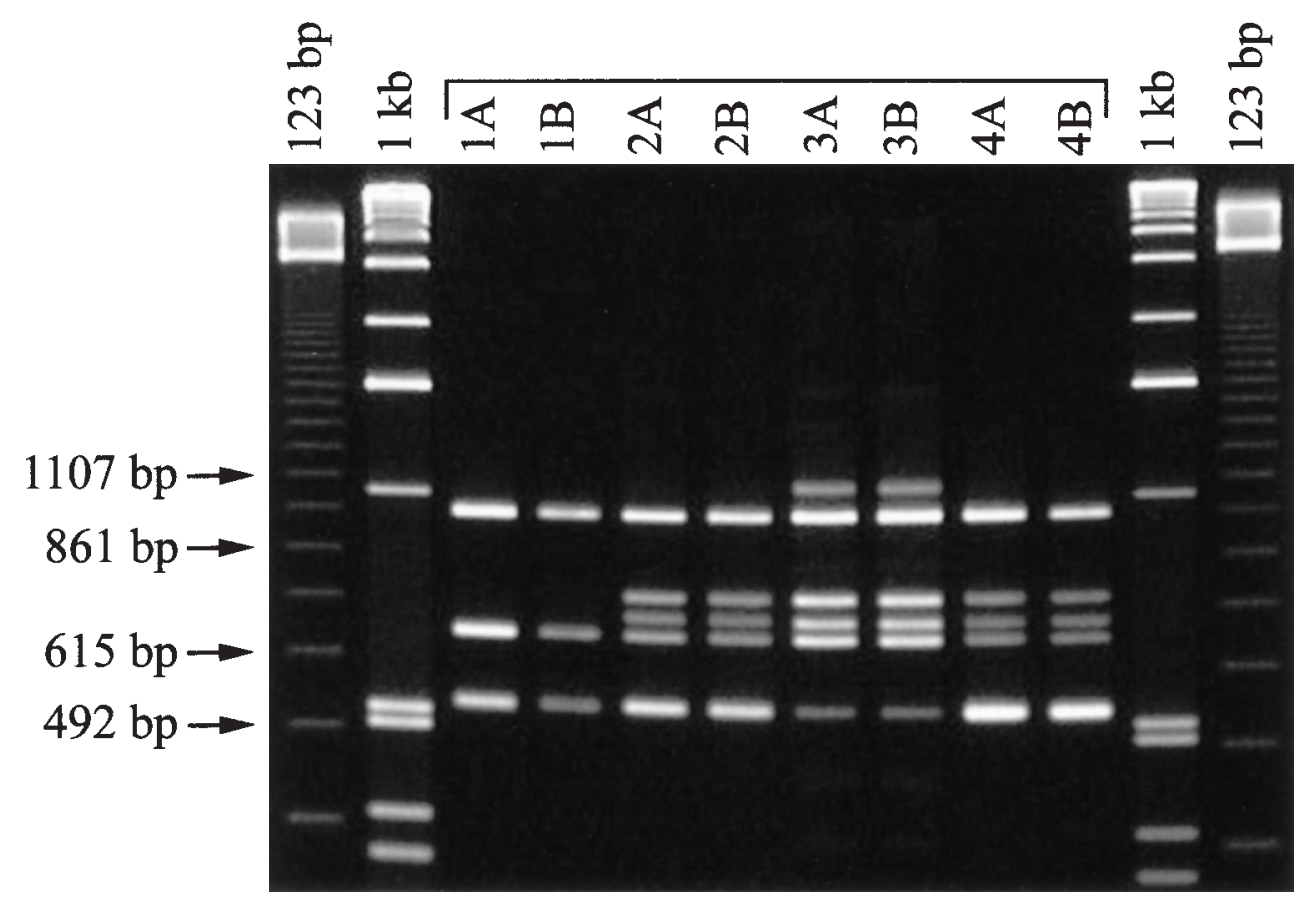

Figure 2: Amplification products from RAPD primer OPAD-13 applied to four pairs of ramets. Both ramets in a pair (e.g., 1A and $1 B$ ) are from a single genet and show the same banding pattern.

tion conditions on our estimates of genet diversity, we isolated DNA from the 17 samples from one set of nested quadrats in the same batch on the same day with the same stock solutions. We then amplified the DNA from those 17 samples on $1 \mathrm{~d}$ with each of the 11 primers. Based on patterns of shared RAPD markers, we calculated Jaccard's genetic distance between all possible pairs of sampled ramets using the RAPDistance Package (Armstrong et al. 1994).

We conducted an additional test to determine the reliability of our RAPD-PCR results in distinguishing ramets and genets. In 1995, from four widely spaced locations at Tomales Bay, we collected pairs of ramets connected together by rhizomes. In 1996, we extracted DNA from one ramet of each genet and stored the DNA at $-80^{\circ} \mathrm{C}$ for 2 yr. In 1998, we extracted DNA from the other ramets that had been stored at $-20^{\circ} \mathrm{C}$ for $3 \mathrm{yr}$. Using different stock solution and on different days, we amplified the previously isolated DNA and the recently isolated DNA with each of the 11 primers used in our study. The patterns of presence or absence of each of the 29 bands were identical between individuals in each of the four pairs of ramets from the same genet (fig. 2). In this control, ramets from the same genet were not mistakenly scored as different genets even when the DNA was handled differently and the RAPD reactions were carried out on different days with different solutions.

\section{A Genetic Marker Cosegregating with Sex}

Bulked segregant analysis has been used successfully to identify RAPD markers linked to gender in at least two plant species (Mulcahy et al. 1992; Hormaza et al. 1994), as well as to detect markers cosegregating with other traits such as disease resistance (Michelmore et al. 1991; Williams et al. 1993; Gmitter et al. 1996). In bulked segregant analysis, DNA from full-sibs is pooled into two groups according to presence or absence of the phenotypic trait of interest. The two pools of DNA are amplified with a series of RAPD primers until primers are found that amplify a band for one DNA pool but not the other.

We used this technique to identify a marker cosegregating with sexual phenotype in D. spicata. Six hundred ten seeds from a single cross between plants from Bodega Bay were washed in $8 \%$ bleach, rinsed with distilled water, put in glass petri dishes with $2 \mathrm{~mL}$ water, wrapped in foil, and left in a growth chamber with a 12-h heat/cool cycle $\left(29^{\circ} / 17^{\circ} \mathrm{C}\right)$. After $10 \mathrm{~d}$, the outer covering of each seed was removed, two drops of fungicide (Captan; Chevron Chemical Co., Ortho, San Ramon, Calif.) solution $(1 \mathrm{mg} / \mathrm{mL}$ water $)$ were added, and the seeds were left to germinate. Germinated seedlings were transferred to sand-filled containers that were kept partially submerged in water with nutrient supplements of $1.0 \%$ am- 
monium, $0.6 \%$ potassium nitrate, $8.4 \%$ urea, $15 \%$ phosphoric acid, and $10 \%$ potash.

Eighteen male plants and 27 female plants $(7.4 \%$ of the $98.5 \%$ of germinated seeds) reached sexual maturity. We removed a 0.1-g sample of leaf from each plant and combined the samples into three female and two male "bulks" of nine plants each. We extracted DNA using the method described above. We amplified the pooled DNA in $25-\mu \mathrm{L}$ PCR reactions with 186 RAPD primers. Three RAPD primers (OPF-13, OPM-16, and OPR-10) amplified a band in all bulks for one sex that did not amplify in the bulks of the other sex. Notably, primer OPF-13 amplified a 450-bp band in the female bulks but not male bulks. We reamplified DNA from all individuals in the bulks with OPF-13. The OPF-13 primer amplified the 450 -bp band in all DNA separately isolated from the 27 female offspring and none of the 18 male offspring.

Next, we verified that primer OPF-13 could be used to distinguish gender in field-collected individuals from the study populations. We amplified DNA from 36 individual plants of known sex collected from Tomales Bay as well as an additional five from Bodega Bay and five from Point Reyes. These plants were sampled at least $1.5 \mathrm{~m}$ apart to reduce the chance of collecting ramets of the same genotype. The OPF-13 primer amplified the 450-bp band from all of the female samples $(n=24)$ and from none of the male samples $(n=22)$. This limited sample permits the assignment of gender to at least $93.7 \%$ of the population with $95 \%$ confidence.

We then used the RAPD marker to sex individuals from the field regardless of their flowering status, a technique pioneered by Lyons et al. (1995) in Silene latifolia. Using the OPF-13 primer, we assayed 77 flowering and 83 nonflowering ramets from the six quadrats at Tomales Bay and the four quadrats at Point Reyes. With one exception (which we omitted from subsequent analyses), in all of the 36 flowering ramets that we recorded as female at the time of collection, the OPF-13 primer amplified the diagnostic 450-bp band. The OPF-13 primer did not amplify the band in any of the 41 flowering male plants. With field-collected plants, the OPF-13 marker correctly classified an individual's sex with $98.7 \%$ accuracy.

\section{Results \\ Spatial Segregation of Male and Female Flowering Ramets}

The focal plant surveys revealed spatial segregation of sexually reproductive ramets by sex at all three sites. Figure 3 shows a comparison of the proportion of male neighbors for male and female focal plants at all sampled distances (1-5 m). We used a maximum-likelihood analysis (PROC CATMOD; SAS Institute 1995) to determine

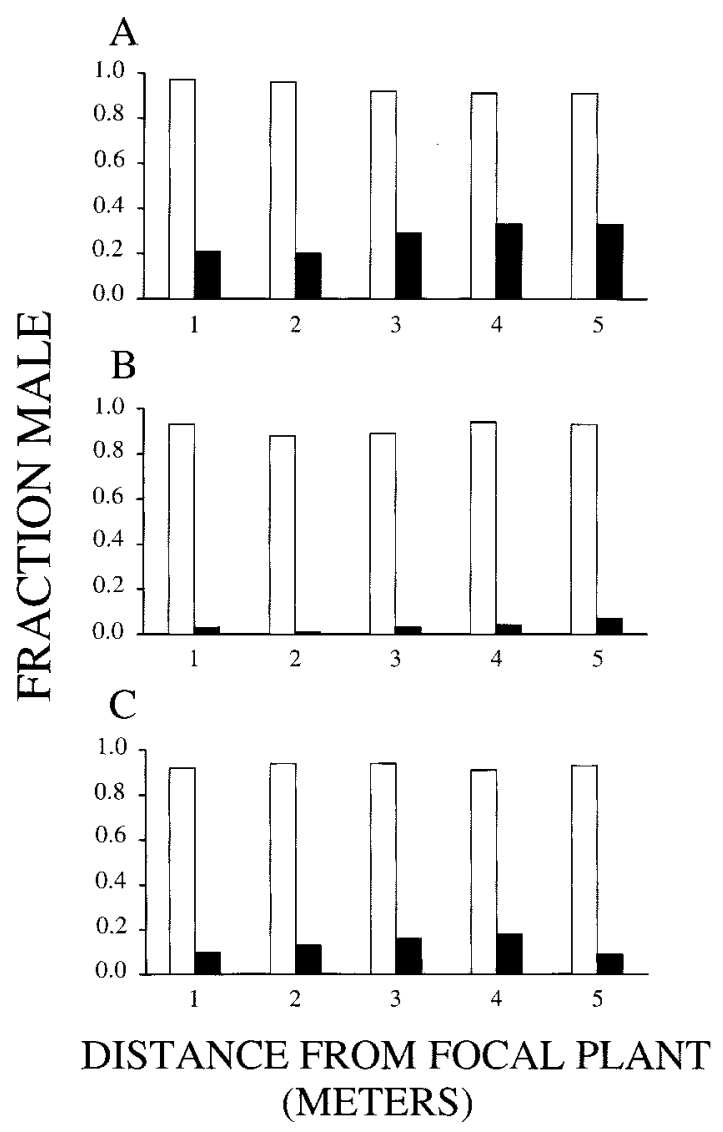

Figure 3: The proportion of sampled ramets that are male as a function of distance from the focal plant. The light bars indicate samples around male focal plants, and the dark bars indicate samples around female focal plants. $A$, Point Reyes; $B$, Tomales Bay; $C$, Bodega Bay.

if the sex of a neighbor was associated with the sex of the focal plant, the distance of the neighbor from the focal plant, or an interaction between the sex of the focal plant and the distance of the neighbor from the focal plant. The analysis shows that sex of the focal plant is the only term significantly associated with the sex of the neighbor at all three sites (Point Reyes: $\chi^{2}=17.66$, df $=1, P<$ .00001 ; Tomales Bay: $\chi^{2}=57.95$, df $=1, P<.00001$; and Bodega Bay: $\chi^{2}=34.72$, df $\left.=1, P<.00001\right)$. Around male focal plants, a greater proportion of neighbors are male, and around female focal plants, a greater proportion of neighbors are female. Neither the distance of the neighbor from the focal plant nor the interaction between distance and the sex of the focal plant are significant terms at Point Reyes $\left(\chi^{2}=0.20\right.$, df $=1, P<$ .6523 and $\chi^{2}=0.00, \mathrm{df}=1, P<.9924$, respectively), Tomales Bay $\left(\chi^{2}=2.12\right.$, df $=1, P<.1457$ and $\chi^{2}=$ 0.74 , df $=1, P<.3898$, respectively), and Bodega Bay $\left(\chi^{2}=0.00, \mathrm{df}=1, P<.9600\right.$ and $\chi^{2}=0.05$, df $=1$, $P<.8155$, respectively). The lack of significant effects of 


\section{The American Naturalist}

distance and the distance $\times$ sex of the focal plant interaction suggest that the spatial extent of both majoritymale areas and majority-female areas of flowering ramets generally exceeds the perimeters of the $78-\mathrm{m}^{2}$ circles we sampled around the focal plants.

\section{Genet Diversity within Majority-Female and Majority-Male Quadrats}

Based on the presence/absence patterns of the 29 polymorphic bands in the 93 sampled ramets from the six quadrats at the Tomales Bay site, we calculated Jaccard's genetic distance (Armstrong et al. 1994) for all pairs of ramets (fig. 4). Using these genetic distances, we reckoned the minimum number of genotypes in each quadrat in two ways. First, we calculated the number of RAPD phenotypes in the least conservative way by assuming that any ramet pairs with even a single difference in their banding represented unique genets. To minimize the possibility that somatic mutations within a genet misleadingly inflated our estimates of genet diversity, we then more conservatively estimated genet number by noting that ramet pairs from the same $10-\mathrm{m}^{2}$ quadrat shared more bands on average $(0 \%-55 \%)$ than pairs from different $10-\mathrm{m}^{2}$ quadrats $(15 \%-70 \%)$. If we assume that ramets from different, well-separated $10-\mathrm{m}^{2}$ quadrats represent unique genets, then we can conservatively estimate the number of genotypes within quadrats by considering as unique genets only ramet pairs that differ by $\geq 15 \%$ of bands. Based on the conservative estimates, from a maximum of nine potential genets, the RAPD markers revealed an average of $4.83(\mathrm{SD}=2.71)$ genets in each $1-\mathrm{m}^{2}$ quadrat and $4.67(\mathrm{SD}=3.21)$ genets in

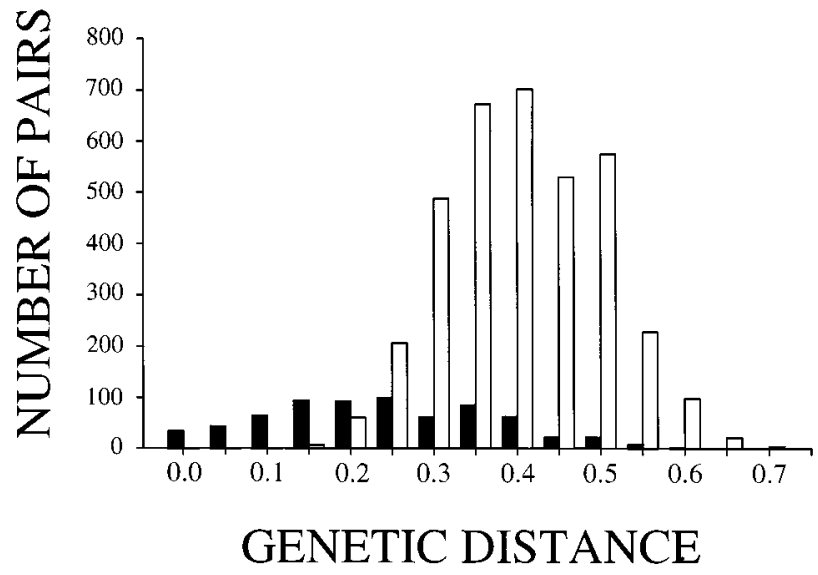

Figure 4: The genetic distance between pairs of individuals sampled in quadrats at Tomales Bay. The dark bars indicate pairs from within a $10-\mathrm{m}^{2}$ quadrat, and the light bars represent pairs between quadrats.
Table 1: Number of genets sampled in quadrats from Tomales Bay

\begin{tabular}{lcccc}
\hline & & & Number of & Minimum \\
Quadrat & Majority & Ramets & RAPD & number of \\
set and size & sex & sampled & phenotypes & genets \\
\hline
\end{tabular}

$1:$

$\begin{array}{llrrr}1 \mathrm{~m}^{2} & \text { Male } & 9 & 9 & 4 \\ 10 \mathrm{~m}^{2} & \text { Male } & 9 & 4 & 2 \\ \text { Pooled } & \text { Male } & 17 & 12 & 5 \\ \text { 2: } & & & & \\ 1 \mathrm{~m}^{2} & \text { Male } & 9 & 7 & 5 \\ 10 \mathrm{~m}^{2} & \text { Male } & 9 & 9 & 8 \\ \text { Pooled } & \text { Male } & 17 & 15 & 13 \\ \text { 3: } & & & & \\ 1 \mathrm{~m}^{2} & \text { Male } & 9 & 7 & 5 \\ 10 \mathrm{~m}^{2} & \text { Male } & 9 & 7 & 11 \\ \text { Pooled } & \text { Male } & 17 & 13 & \end{array}$

4:

$\begin{array}{lllll}1 \mathrm{~m}^{2} & \text { Female } & 8 & 8 & 6\end{array}$

$\begin{array}{lllll}10 \mathrm{~m}^{2} & \text { Female } & 9 & 9 & 6\end{array}$

$\begin{array}{lllll}\text { Pooled } & \text { Female } & 16 & 16 & 11\end{array}$

5:

$\begin{array}{lllll}1 \mathrm{~m}^{2} & \text { Female } & 5 & 3 & 2\end{array}$

$\begin{array}{lllll}10 \mathrm{~m}^{2} & \text { Female } & 8 & 5 & 3\end{array}$

Pooled $\quad$ Female $\quad 13 \quad 5 \quad 5$

6:

$\begin{array}{lllll}1 \mathrm{~m}^{2} & \text { Female } & 8 & 7 & 6\end{array}$

$10 \mathrm{~m}^{2} \quad$ Female $\quad 6 \quad 6 \quad 6 \quad 4$

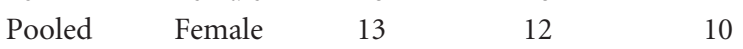

each $10-\mathrm{m}^{2}$ quadrat (table 1 ). On average, in each quadrat set (samples pooled from the $1-\mathrm{m}^{2}$ quadrat and the $10-\mathrm{m}^{2}$ quadrat at each location), the markers distinguished $9.17(\mathrm{SD}=4.23$ ) genets out of a maximum of 17. These values must underestimate the true number of genets in the quadrats since the samples themselves represent a tiny fraction of all Distichlis spicata in the sampled quadrats $\left(\bar{X}=4,666 ; \mathrm{SD}=2,584\right.$ ramets $/ \mathrm{m}^{2}$ at Tomales Bay).

\section{Spatial Distribution of Gender in Flowering and Nonflowering Ramets}

Using the OPF-13 marker linked to female phenotype, we determined the sex of all ramets (flowering and nonflowering) for samples at two of the field sites, Tomales Bay (table 2) and Point Reyes (table 3). We used individual $G$-tests to determine if the sex ratios of all ramets, flowering ramets, and nonflowering ramets differed significantly from $1: 1$ in each $10-\mathrm{m}^{2}$ quadrat. We then analyzed our data for quadrats of the same majority sex (as determined by previous samples of 100 flowering ramets) 
Table 2: Sex ratios for flowering and nonflowering ramets at Tomales Bay

\begin{tabular}{|c|c|c|c|c|c|c|c|c|c|c|c|c|c|c|c|}
\hline \multirow[b]{2}{*}{ Quadrat } & \multicolumn{5}{|c|}{ All ramets } & \multicolumn{5}{|c|}{ Flowering ramets } & \multicolumn{5}{|c|}{ Nonflowering ramets } \\
\hline & $\mathrm{n}$ & $\%$ male & $d f$ & G & $\mathrm{P}$ & $\mathrm{n}$ & $\%$ male & $d f$ & G & $\mathrm{P}$ & $\mathrm{n}$ & $\%$ male & $d f$ & G & $\mathrm{P}$ \\
\hline \multicolumn{16}{|c|}{$\begin{array}{l}\text { Quadrats with majorities } \\
\text { of male flowering } \\
\text { ramets: }\end{array}$} \\
\hline 1 & 17 & 100 & 1 & 23.57 & $* * *$ & 6 & 100 & 1 & 8.32 & ** & 11 & 100 & 1 & 15.25 & $* * *$ \\
\hline 2 & 17 & 71 & 1 & 2.97 & NS & 6 & 100 & 1 & 8.32 & ** & 11 & 55 & 1 & .09 & NS \\
\hline 3 & 17 & 59 & 1 & .53 & NS & 6 & 100 & 1 & 8.32 & $* *$ & 11 & 36 & 1 & .83 & NS \\
\hline$G_{\mathrm{T}}$ & $\cdots$ & $\cdots$ & 3 & 27.07 & $* * *$ & $\cdots$ & $\cdots$ & 3 & 24.96 & $* * *$ & $\cdots$ & $\cdots$ & 3 & 16.17 & $* *$ \\
\hline$G_{\mathrm{P}}$ & $\cdots$ & $\cdots$ & 1 & 15.05 & $* * *$ & $\cdots$ & $\cdots$ & 1 & 24.95 & $* * *$ & $\cdots$ & $\cdots$ & 1 & 2.49 & NS \\
\hline$G_{\mathrm{H}}$ & $\cdots$ & $\cdots$ & 2 & 12.02 & $* *$ & $\cdots$ & $\cdots$ & 2 & .01 & NS & $\cdots$ & $\cdots$ & 2 & 13.68 & $* *$ \\
\hline \multicolumn{16}{|c|}{$\begin{array}{l}\text { Quadrats with majorities } \\
\text { of female flowering } \\
\text { ramets: }\end{array}$} \\
\hline 4 & 16 & 6 & 1 & 14.70 & $* * *$ & 3 & 0 & 1 & 4.16 & * & 13 & 8 & 1 & 10.97 & $* * *$ \\
\hline 5 & 13 & 23 & 1 & 3.98 & * & 2 & 50 & 1 & .00 & NS & 11 & 18 & 1 & 4.82 & * \\
\hline 6 & 13 & 31 & 1 & 1.97 & NS & 6 & 0 & 1 & 8.32 & $* *$ & 7 & 57 & 1 & .14 & NS \\
\hline$G_{\mathrm{T}}$ & $\ldots$ & $\ldots$ & 3 & 20.65 & $* * *$ & $\cdots$ & $\ldots$ & 3 & 12.48 & $* *$ & $\ldots$ & $\ldots$ & 3 & 15.93 & $* *$ \\
\hline$G_{\mathrm{P}}$ & $\cdots$ & $\cdots$ & 1 & 17.32 & $* * *$ & $\cdots$ & $\cdots$ & 1 & 8.54 & $* *$ & $\cdots$ & $\cdots$ & 1 & 9.86 & $* *$ \\
\hline$G_{\mathrm{H}}$ & $\cdots$ & $\cdots$ & 2 & 3.33 & NS & $\cdots$ & $\cdots$ & 2 & 3.94 & NS & $\cdots$ & $\cdots$ & 2 & 6.07 & $*$ \\
\hline
\end{tabular}

Note: $G$ is a statistic calculated to determine if the sex ratio of each quadrat is significantly different from $1: 1 . G_{\mathrm{T}}$ is the $G$ statistic calculated by summing the $G$ 's from all quadrats with the same majority sex. $G_{\mathrm{p}}$ is the $G$ statistic calculated by pooling the data from all sampled ramets from all quadrats with the same majority sex. $G_{\mathrm{H}}$ is the $G$ statistic that is the difference between $G_{\mathrm{T}}$ and $G_{\mathrm{P}}$.

${ }^{*} P<.05$.

${ }^{* *} P<.01$.

${ }^{* * *} P<.001$.

separately for the Tomales Bay and for the Point Reyes sites. For these analyses, we calculated the following $G$ statistics (Sokal and Rohlf 1995, pp. 715-724): $G_{\mathrm{T}}$ (the $G$ statistic calculated by summing the $G$ 's from all of the quadrats with the same majority sex at the same site), $G_{\mathrm{P}}$ (the $G$ statistic calculated by pooling the data from all sampled ramets from all of the quadrats with the same majority sex at the same site), and $G_{\mathrm{H}}$ (the $G$ statistic that is the difference between $G_{\mathrm{T}}$ and $G_{\mathrm{P}}$ ). A significant $G_{\mathrm{T}}$ indicates that, at the level of quadrats with the same majority sex at a site, sex ratios differed significantly from $1: 1$ (although quadrats may differ from one another in the direction in which their sex ratio is skewed from 1:1); a significant $G_{\mathrm{P}}$ indicates that the sex ratio of sampled ramets pooled from all quadrats of the same majority sex at a site differed significantly from 1:1; and a significant $G_{\mathrm{H}}$ indicates that the sex ratios of the quadrats with the same majority sex at the same site differed significantly from one another.

With the one exception of nonflowering ramets in male-majority quadrats at Tomales Bay, at both sites $G_{\mathrm{T}}$ and $G_{\mathrm{P}}$ are significant for flowering and nonflowering ramets taken separately or together, regardless of whether the quadrats had male or female majorities of flowering ramets (tables 2 and 3). In all cases including the exceptional one, ramet sex ratios of pooled data for quadrats with the same majority sex at the same site were skewed toward the majority sex of each quadrat, as determined from previously sampled flowering ramets. In three cases at Tomales Bay, involving nonflowering ramets in male-majority quadrats, all ramets (flowering and nonflowering together) in male-majority quadrats, and nonflowering ramets in female-majority quadrats, $G_{\mathrm{H}}$ was significant, suggesting that sex ratios varied among quadrats. Notably, the sex ratio of nonflowering ramets in one of the three male-majority quadrats was skewed toward females, and the sex ratio of nonflowering ramets in one of the three female-majority quadrats was skewed slightly toward males.

We used a maximum-likelihood analysis (PROC CATMOD; SAS Institute 1995) to determine if the sex of a sampled ramet was associated with the majority sex of flowering ramets in the sampled quadrat (male vs. female), the flowering status of that ramet (flowering or nonflowering), and the interaction between these two predictor variables. The majority sex of flowering ramets is significantly associated with the sex of sampled ramets $\left(\chi^{2}=34.04, P<.00001\right)$. Thus, regardless of flowering 
666 The American Naturalist

Table 3: Sex ratios for flowering and nonflowering ramets at Point Reyes

\begin{tabular}{|c|c|c|c|c|c|c|c|c|c|c|c|c|c|c|c|}
\hline \multirow[b]{2}{*}{ Quadrat } & \multicolumn{5}{|c|}{ All ramets } & \multicolumn{5}{|c|}{ Flowering ramets } & \multicolumn{5}{|c|}{ Nonflowering ramets } \\
\hline & $\mathrm{n}$ & $\%$ male & $d f$ & G & $\mathrm{P}$ & $\mathrm{n}$ & $\%$ male & $d f$ & G & $\mathrm{P}$ & $\mathrm{n}$ & $\%$ male & $d f$ & G & $\mathrm{P}$ \\
\hline \multicolumn{16}{|c|}{$\begin{array}{l}\text { Quadrats with majorities } \\
\text { of male flowering } \\
\text { ramets: }\end{array}$} \\
\hline 1 & 16 & 100 & 1 & 22.18 & $* * *$ & 15 & 100 & 1 & 20.79 & $* * *$ & 1 & 100 & 1 & 1.39 & NS \\
\hline 2 & 17 & 94 & 1 & 15.96 & $* * *$ & 7 & 86 & 1 & 3.96 & * & 10 & 100 & 1 & 13.86 & $* * *$ \\
\hline$G_{\mathrm{T}}$ & $\cdots$ & $\cdots$ & 2 & 38.14 & $* * *$ & $\cdots$ & $\cdots$ & 2 & 24.75 & $* * *$ & $\cdots$ & $\cdots$ & 2 & 15.25 & $* * *$ \\
\hline$G_{\mathrm{P}}$ & $\cdots$ & $\cdots$ & 1 & 36.79 & $* * *$ & $\cdots$ & $\cdots$ & 1 & 22.36 & $* * *$ & $\cdots$ & $\cdots$ & 1 & 15.25 & $* * *$ \\
\hline$G_{\mathrm{H}}$ & $\cdots$ & $\cdots$ & 1 & 1.35 & NS & $\cdots$ & $\cdots$ & 1 & 2.39 & NS & $\cdots$ & $\cdots$ & 1 & .00 & NS \\
\hline \multicolumn{16}{|c|}{$\begin{array}{l}\text { Quadrats with majorities } \\
\text { of female flowering } \\
\text { ramets: }\end{array}$} \\
\hline 3 & 17 & 0 & 1 & 23.57 & $* * *$ & 15 & 0 & 1 & 20.79 & $* * *$ & 2 & 0 & 1 & 2.77 & NS \\
\hline 4 & 17 & 0 & 1 & 23.57 & $* * *$ & 11 & 0 & 1 & 15.25 & $* * *$ & 6 & 0 & 1 & 8.32 & $* *$ \\
\hline$G_{\mathrm{T}}$ & $\ldots$ & $\ldots$ & 2 & 47.14 & $* * *$ & $\ldots$ & $\ldots$ & 2 & 36.04 & $* * *$ & $\ldots$ & $\ldots$ & 2 & 11.09 & $* *$ \\
\hline$G_{\mathrm{P}}$ & $\ldots$ & $\ldots$ & 1 & 47.13 & $* * *$ & $\ldots$ & $\ldots$ & 1 & 36.04 & $* * *$ & $\ldots$ & $\ldots$ & 1 & 11.09 & $* * *$ \\
\hline$G_{\mathrm{H}}$ & $\ldots$ & $\ldots$ & 1 & .01 & NS & $\cdots$ & $\ldots$ & 1 & .00 & NS & $\cdots$ & $\ldots$ & 1 & .00 & NS \\
\hline
\end{tabular}

Note: $G$ is a statistic calculated to determine if the sex ratio of each quadrat is significantly different from $1: 1 . G_{\mathrm{T}}$ is the $G$ statistic calculated by summing the $G$ 's from all quadrats with the same majority sex. $G_{\mathrm{P}}$ is the $G$ statistic calculated by pooling the data from all sampled ramets from all quadrats with the same majority sex. $G_{\mathrm{H}}$ is the $G$ statistic that is the difference between $G_{\mathrm{T}}$ and $G_{\mathrm{p}}$.

${ }^{*} P<.05$.

$* * P<.01$.

${ }^{* * *} P<.001$.

status, male ramets occur more often in quadrats with a majority of male flowering ramets, and female ramets occur more often in quadrats with a majority of female flowering ramets. In addition, the significant interaction between the majority sex and flowering status $\left(\chi^{2}=\right.$ 14.19, $P<.00001$ ) shows that in majority-male quadrats males are more likely to be in flower than females, and in majority-female quadrats females are more likely to be in flower than males. The association between ramet flowering status and sex is not significant $\left(\chi^{2}=0.05\right.$, $P<.8316)$.

\section{Genet Sex Ratios}

By combining our data on the number of genets in a given quadrat with the sex of sampled ramets, we can infer sex ratios at the level of genets rather than ramets. Our data on numbers of genets per quadrat is limited to Tomales Bay; consequently, we analyzed genet sex ratios only for quadrats from this site (fig. 5). To some extent, small sample sizes limited our ability to detect significant departures from a 1:1 sex ratio within individual quadrats. Indeed, only quadrats 2 and 4 had genet sex ratios extreme enough to differ significantly from $1: 1$. We separately calculated $G$ statistics for combined data from quadrats with male majorities of flowering ramets $\left(G_{\mathrm{T}}=\right.$

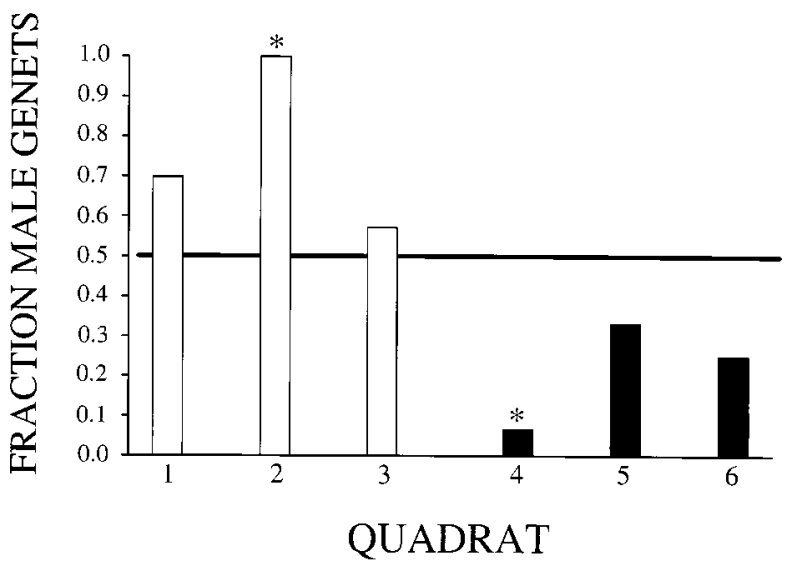

Figure 5: The fraction of male genets in samples $(n=13-17)$ identified in each of six quadrats at Tomales Bay. Light bars indicate genet sex ratios for samples taken from quadrats with majorities of male flowering ramets. Dark bars indicate genet sex ratios for samples taken from quadrats with majorities of female flowering ramets. The asterisks over bars 2 and 4 indicate that these sex ratios are significantly different from $1: 1$ (the $G$ statistic has a $P$ value less than .05). 
18.63, $P<.001$ and $\left.G_{\mathrm{P}}=9.15, P<.01\right)$ and from quadrats with female majorities of flowering ramets $\left(G_{\mathrm{T}}=\right.$ 18.86, $P<.001$ and $\left.G_{\mathrm{P}}=15.40, P<.001\right)$. Thus, for samples that included both flowering and nonflowering individuals, genet sex ratios, like ramet sex ratios, were skewed from 1:1 in the direction of the majority sex of previously sampled flowering ramets.

\section{Discussion}

Consistent with previous field surveys (Freeman et al. 1976; Bertness et al. 1987), our study shows that in three populations of Distichlis spicata flowering ramets are more likely to have neighbors of the same sex than of the opposite sex. There are three simple explanations for this pattern of spatial segregation of flowering ramets that do not involve true spatial segregation of the sexes. First, because $D$. spicata propagates asexually by rhizomes, patches exhibiting gender bias may merely be the result of local asexual proliferation by one or a few genets. Indeed, in a survey of 10 plant species, Iglesias and Bell (1989) found that asexually propagating species were more likely to show a patchy distribution of males and females than species that only reproduce sexually. Our genetic analysis of $D$. spicata revealed that a high proportion of sampled ramets in each patch exhibiting gender bias represents distinct RAPD phenotypes. Even our most conservative estimates of genet diversity reveal that at least $50 \%$ of the sampled ramets represent distinct genotypes, suggesting that somatic mutations did not substantially inflate our estimates of genetic diversity. Vegetative spread by a few established genets is inconsistent with this pattern.

Second, spatial segregation of flowering ramets could be caused by differential rates of clonal growth for males and females in different habitats. In some species, males and females do grow at different rates, and these differences can be environment dependent (Grant and Mitton 1979; Dawson and Bliss 1989). If differential clonal growth were producing locally biased sex ratios in our study populations, counts of ramets would yield skewed sex ratios within patches, but the genet sex ratio would still be close to $1: 1$. Instead, at Tomales Bay we showed that patches with skewed ramet sex ratios also have genet sex ratios that differ from $1: 1$. Thus, gender-specific differences in rates of clonal growth do not appear to be the primary cause of spatial segregation of flowering ramets in D. spicata. Nevertheless, if there were such differences and if larger genets consistently drove smaller genets to extinction, then a genet sex ratio deviating from $1: 1$ would be expected. This seems an unlikely explanation for spatial segregation of the sexes in D. spicata because most ramets we sampled represented unique genotypes.
Third, if a large portion of a population is not flowering, as is the case in the populations of D. spicata we studied, the population may appear to be spatially segregated with respect to sex, but this pattern could arise simply because male and female plants differentially flower in different microhabitats. On the basis of femalespecific RAPD markers, our study shows that, in patches with majorities of either male or female flowering ramets, sex ratios for all ramets (flowering and nonflowering) significantly differed from 1:1. Hence, differential flowering of the sexes among different environments cannot fully explain spatial segregation of flowering ramets in these populations. However, the statistical interaction between the majority sex of flowering ramets and a ramet's flowering status shows that site-specific differences in flowering of males and females also contribute to spatial segregation among flowering individuals. Nonetheless, patches with male and female majorities of flowering ramets include many genets, and the majority of individuals, both flowering and not, are the same sex. Thus, there is true spatial segregation of sexes in these populations.

Whatever the benefits of spatial segregation of the sexes, there are potentially significant costs (Bierzychudek and Eckhart 1988). The most general potential cost of spatial segregation of the sexes is a reduction in reproductive success due to fertilization limitation (Bawa and Opler 1977; Meagher 1980, 1984; Cox 1981). Preliminary studies in D. spicata show that pollen dispersal is spatially restricted and that the vast majority of ovules do not mature into seeds (S. M. Eppley, unpublished data). The existence and magnitude of other costs depends to some degree on the proximate mechanisms that generate spatial segregation of the sexes. For example, in cases where environmental sex determination leads to spatial segregation of the sexes (Bierzychudek 1982; Lovett Doust and Cavers 1982; Freeman and Vitale 1985; Vitale and Freeman 1986; Zimmerman 1991), the costs due to genderspecific mortality should be relatively low. However, the cosegregation of a RAPD marker with female phenotype indicates that sex is genetically controlled in D. spicata. Unless male and female seeds exhibit biased dispersal into their favored habitats, genetic control of gender in species spatially segregated by sex must entail genderspecific mortality.

Because sex is genetically determined in D. spicata, environmental heterogeneity must enforce spatial segregation of the sexes such that male and female genotypes are favored in different microhabitats. In the Tomales Bay populations, where we carried out the bulk of our work, environments with male and female majorities differ significantly topographically (S. M. Eppley, unpublished data), and in the greenhouse, experimentally manipulated differences in topography significantly affect D. spi- 
cata seeds (S. M. Eppley, unpublished data). To the extent that dispersal of male and female seeds is effectively random with respect to topography, gender-specific differences in germination success or postgermination mortality rates within these different topographic microenvironments must yield spatial segregation of the sexes.

Given the decrease in mating success and increase in offspring mortality potentially associated with spatial segregation of males and females, counterbalancing selection or genetic constraints are likely to be maintaining spatial segregation of the sexes in D. spicata. A male genotype that could succeed within a microhabitat with a female majority would presumably enjoy disproportionately high mating success compared with males in areas with male majorities. If genetic variation for this broader ecological amplitude existed within a given sex, then variation in mating success should lead to dominance by genotypes without strict gender-specific habitat requirements. That such a response has not occurred in populations of D. spicata exhibiting spatial segregation of the sexes may be due to some combination of counterbalancing selection favoring individuals that flourish in habitats with neighbors of their same sex and lack of variation for broader ecological amplitude. Evaluation of the relative contributions of selection and phylogenetic history to the evolution of spatial segregation of the sexes in D. spicata and other taxa ultimately requires identification of the costs and benefits of this pattern, as well as a phylogenetic analysis of the association between mechanisms of sex determination and spatial segregation of the sexes.

\section{Acknowledgments}

We thank B. Cameron, L. Caris, B. Seeley, and A. Shaw for help in the lab. We are grateful to E. Baack, C. Christian, K. Holsinger, D. Posner, K. Ritland, L. Rose, B. Roy, and two anonymous reviewers for their valuable comments on earlier drafts of this manuscript. Research was supported by National Science Foundation (NSF) grant OCE 94-02797 to R.K.G.; NSF grant IBN 94-19800 to M.L.S.; and University of California Bodega Marine Laboratory travel grants, research awards from the Center for Population Biology at the University of California, Davis, NSF grant DEB 97-01338, and a U.S. Environmental Protection Agency STAR fellowship to S.M.E.

\section{Literature Cited}

Armstrong, J. E., and A. K. Irvine. 1989. Flowering, sex ratios, pollen ovule ratios, fruit set, and reproductive effort of a dioecious tree, Myristica insipida (Myristica- ceae), in two different rain forest communities. American Journal of Botany 76:74-85.

Armstrong, J. S., A. J. Gibbs, R. Peakall, and G. Weiller. 1994. The RAPDistance package. ftp://life.anu.edu.au/ pub/software/RAPDistance.

Babcock, R. C., and C. N. Mundy. 1992. Reproductive biology, spawning and field fertilization rates of Acanthaster planci. Australian Journal of Marine and Freshwater Research 43:525-534.

Bawa, K. S., and P. A. Opler. 1977. Spatial relationships between staminate and pistillate plants of dioecious tropical forest trees. Evolution 31:64-68.

Beetle, A. 1943. The North American variations of Distichlis spicata. Bulletin of the Torrey Botanical Club 70: 638.

Bertness, M. D., C. Wise, and A. M. Ellison. 1987. Consumer pressure and seed set in a salt marsh perennial plant community. Oecologia (Berlin) 71:190200.

Bierzychudek, P. 1982. The demography of jack-in-thepulpit, a forest perennial that changes sex. Ecological Monographs 52:335-351.

Bierzychudek, P., and V. Eckhart. 1988. Spatial segregation of the sexes of dioecious plants. American Naturalist 132:34-43.

Brazeau, D. A., and H. R. Lasker. 1992. Reproductive success in a marine benthic invertebrate, the Caribbean octocoral Briareum asbestinum. Marine Biology 114:157-163.

Bullock, S. H. 1982. Population structure and reproduction in the neotropical dioecious tree Compsoneura sprucei. Oecologia (Berlin) 55:238-242.

Burczyk, J., W. T. Adams, and J. Y. Shimiza. 1996. Mating patterns and pollen dispersal in a natural knobcone pine (Pinus attenuata Lemmon.) stand. Heredity 77:251-260.

Cipollini, M. L., and E. W. Stiles. 1991. Costs of reproduction in Nyssa sylvatica: sexual dimorphism in reproductive frequency and nutrient flux. Oecologia (Berlin) 86:585-593.

Cox, P. A. 1981. Niche partitioning between sexes of dioecious plants. American Naturalist 117:295-307.

Cresswell, J. E., A. P. Basson, S. A. Bell, S. J. Collins, and T. B. Kelley. 1995. Predicted pollen dispersal by honeybees and three species of bumble-bees foraging on oilseed rape: a comparison of three models. Functional Ecology 9:829-841.

Dawson, T. E., and L. C. Bliss. 1989. Patterns of water use and the tissue water relations in the dioecious shrub, Salix arctica: the physiological basis for habitat partitioning between the sexes. Oecologia (Berlin) 79: 332-343. 
Freeman, D. C., and J. J. Vitale. 1985. The influence of environment on the sex ratio and fitness of spinach. Botanical Gazette 146:137-142.

Freeman, D. C., L. G. Klikoff, and K. T. Harper. 1976. Differential resource utilization by the sexes of dioecious plants. Science (Washington, D.C.) 193:597599.

Gmitter, F. G., Jr., S. Y. Xiao, S. Huang, X. L. Hu, S. M. Garnsey, and Z. Deng. 1996. A localized linkage map of the citrus tristeza virus resistance gene region. Theoretical and Applied Genetics 92:688-695.

Grant, M. C., and J. B. Mitton. 1979. Elevational gradients in adult sex ratios and sexual differentiation in vegetative growth rates of Populus tremuloides Michx. Evolution 33:914-918.

Guitian, J. 1995. Sex ratio, reproductive investment and flowering phenology in dioecious Rhamnus alaternus (Rhamnaceae). Nordic Journal of Botany 15:139143.

Hancock, J. F., and R. S. Bringhurst. 1980. Sexual dimorphism in the strawberry Fragaria chiloensis. Evolution 34:762-768.

Hitchcock, A. S. 1971. Manual of the grasses of the United States. Dover, New York.

Hoffmann, R. J. 1986. Variation in contributions of asexual reproduction to the genetic structure of populations of the sea anemone Metridium senile. Evolution 40:357-365.

Hormaza, J. I., L. Dollo, and V. S. Polito. 1994. Identification of a RAPD marker linked to sex determination in Pistacia vera using bulked segregant analysis. Theoretical Applied Genetics 89:9-13.

Houssard, C., J. D. Thompson, and J. Escarre. 1994. Do sex-related differences in response to environmental variation influence the sex-ration in the dioecious $R u$ mex acetosella? Oikos 70:80-90.

Hunter, C. L. 1993. Genotypic variation and clonal structure in coral populations with different disturbance histories. Evolution 47:1213-1228.

Iglesias, M. C., and G. Bell. 1989. The small-scale spatial distribution of male and female plants. Oecologia (Berlin) 80:229-235.

Korpelainen, H. 1991. Sex ratio variation and spatial segregation of the sexes in populations of Rumex acetosa and $R$. acetosella (Polygonaceae). Plant Systematics and Evolution 174:183-195.

Levitan, D. R. 1991. Influence of body size and population density on fertilization success and reproductive output in a free-spawning invertebrate. Biological Bulletin (Woods Hole) 181:261-268.

Levitan, D. R., and R. K. Grosberg. 1993. The analysis of paternity and maternity in the marine hydrozoan $\mathrm{Hy}$ - dactinia symbiolongicarpus using randomly amplified polymorphic DNA (RAPD) markers. Molecular Ecology 2:315-326.

Levitan, D. R., Sewell, M. A., and F.-S. Chia. 1992. How distribution and abundance influence fertilization success in the sea urchin Strongylocentrotus franciscanus. Ecology 73:248-254.

Lloyd, D. G. 1973. Sex ratios in sexual dimorphic Umbelliferae. Heredity 31:239-249.

Lovett Doust, J., and P. B. Cavers. 1982. Sex and gender dynamics in jack-in-the-pulpit, Arisaema triphyllum (Araceae). Ecology 63:797-808.

Lovett Doust, J., G. O’Brien, and L. Lovett Doust. 1987. Effect of density on secondary sex characteristics and sex ratio in Silene alba (Caryophyllaceae). American Journal of Botany 74:40-46.

Lyons, E. E., N. Shah-Mahoney, and L. A. Lombard. 1995. Evolutionary dynamics of sex ratio and gender dimorphism in Silene latifolia. II. Sex ratio and flowering status in a potentially male-biased population. Journal of Heredity 86:107-113.

Meagher, T. R. 1980. Population biology of Chamaelirium luteum, a dioecious lily. I. Spatial distributions of males and females. Evolution 34:1127-1137.

- 1984. Sexual dimorphism and ecological differentiation of male and female plants. Annals of the Missouri Botanical Garden 71:254-264.

Melampy, M. N., and H. F. Howe. 1977. Sex ratio in the tropical tree Triplaris americana (Polygonaceae). Evolution 31:867-872.

Michelmore, R. W., I. Paran, and R. V. Kesseli. 1991. Identification of markers linked to disease-resistance genes by bulked segregant analysis: a rapid method to detect markers in specific genomic regions by using segregating populations. Proceedings of the National Academy of Sciences of the USA 88:9828-9832.

Mulcahy, D. L., N. F. Weeden, R. Kesseli, and S. B. Carroll. 1992. DNA probes for the Y-chromosome of Silene latifolia, a dioecious angiosperm. Sexual Plant Reproduction 5:86-88.

Pennington, J. T. 1985. The ecology of fertilization of echinoid eggs: the consequences of sperm dilution, adult aggregation, and synchronous spawning. Biological Bulletin (Woods Hole) 169:417-430.

Saghai-Maroof, M. A., K. M. Soliman, R. A. Jorgensen, and R. W. Allard. 1984. Ribosomal DNA spacer-length polymorphisms in barley: Mendelian inheritance, chromosomal location, and population dynamics. Proceedings of the National Academy of Sciences of the USA 81:8014-8018.

SAS Institute. 1995. The SAS system for Windows. Release 6.11. SAS Institute, Cary, N.C. 


\section{The American Naturalist}

Shea, M. M., P. M. Dixon, and R. R. Sharitz. 1993. Size differences, sex ratio, and spatial distribution of male and female water tupelo, Nyssa aquatica (Nyssaceae). American Journal of Botany 80:26-30.

Sokal, R. R., and F. J. Rohlf. 1995. Biometry. W. H. Freeman, New York.

Taylor, D. R. 1996. The genetic basis of sex ratio in Silene alba (S. latifolia). Genetics 136:641-651.

Vitale, J. J., and D. C. Freeman. 1986. Partial niche separation in Spinacia oleracea L.: an examination of reproductive allocation. Evolution 40:426-430.

Wade, K. M., R. A. Armstrong, and S. R. J. Woodell. 1981. Experimental studies on the distribution of the sexes of Mercurialis perennis L. I. Field observations and canopy removal experiments. New Phytologist 87: 431-438.
Williams, J. G. K., R. S. Reiter, R. M. Young, and P. A. Scolnik. 1993. Genetic mapping of mutations using phenotypic pools and mapped RAPD markers. Nucleic Acids Research 21:2697-2702.

Yund, P. O. 1990. An in situ measurement of sperm dispersal in a clonal marine hydroid. Journal of Experimental Zoology 253:102-106.

Yund, P. O., and H. M. Parker. 1989. Population structure of the colonial hydroid Hydractinia sp. nov. C in the Gulf of Maine (USA). Journal of Experimental Marine Biology and Ecology 125:63-82.

Zimmerman, J. K. 1991. Ecological correlates of labile sex expression in the orchid Catasetum viridiflavum. Ecology 72:597-608.

Associate Editors: Kermit Ritland Kent E. Holsinger 